https://doi.org/10.31426/ijamsr.2018.1.10.1020

I J A M S R

International Journal of

Advanced Multidisciplinary Scientific Research (IJAMSR) ISSN:2581-4281

\title{
SURVEY OF THE SPIRITUAL INTELLIGENCE AMONG POST- GRADUATE STUDENTS OF KASHMIR WITH RESPECT TO GENDER AND LOCALE
}

\author{
Jan Jahanger ${ }^{1 *}$, Dr. Aneet Kumar ${ }^{2}$
}

1Research scholar, University Institute of Education, Sant Baba Bhag Singh University, Punjab, India. 2Dean, University Institute of Education, Sant Baba Bhag Singh University, Punjab, India.

Email: janjahangir74@gmail.com

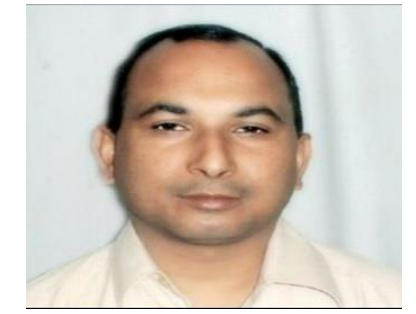

DR. ANEET KUMAR

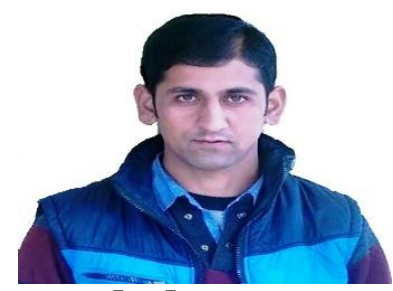

JAN JAHANGER

\begin{abstract}
A B S T R A C T
The purpose of this study was to study the spiritual intelligence of post-graduate students of Kashmir division of Jammu and Kashmir. For the study a total sample of 302 individual subjects divided into two divisions of 152 males comprising of 76 rural \& 76 urban and150 females comprising of 75 rural \& 75 urban. The tool used for data collection was Spiritual intelligence scale developed by K.S. Mishra (2014). For this study the statistical tools used to be Mean, Standard Deviation and t-test. The findings of the study reveal that there is an insignificant difference in the spiritual intelligence between male and female students as well as between rural and urban students.
\end{abstract}

Citation: Jan Jahanger, Dr. Aneet Kumar (2018). Survey Of The Spiritual Intelligence Among Post-Graduate Students Of Kashmir With Respect To Gender And Locale. International Journal of Advanced Multidisciplinary Scientific Research (IJAMSR ) ISSN:2581-4281 Vol 1, Issue 10, December, 2018, \#Art.1020, pp 88-94

\footnotetext{
Keywords:

Postgraduate

Students, Spiritual Intelligence, male \& female students, rural \& urban students.
}

\section{Introduction}

The idea of spiritual intelligence was first brought up in the scholarly writing in psychology by Stevens (1996) in her book, Spirituality in Nursing: from Traditional to New age, and afterward in 1999 by Emmons. Spiritual intelligence was coined and presented by Danah Zohar (2000). The word spiritual in the Zohar/Marshal idea originates from the Latin word Spiritus, which signifies, 


\section{International Journal of Advanced Multidisciplinary Scientific Research (IJAMSR) ISSN:2581-4281}

"that which gives life or vitality to a system ". At that point Danah Zohar and Ian Marshal consolidated and researched on SI and characterized it as the intelligence with which issues identified with importance and esteem are tended to and explained. It is an intelligence with which one will plan and place one's activities and one's life in a more extensive, more extravagant, which means giving setting. Spiritual intelligence is the intelligence with which one can get to one's most profound implications, purposes, and most elevated inspirations. It is the intelligence with which principal question is asked and with which answers are reformed. SI turns into a type of "hyper thinking offering ascend to" means giving, contextualizing, and transformative intelligence. Sisk and Torrance (2001) defines Spiritual Intelligence as the ability to use a multi-sensory approach to problem solving and to learn to listen to your inner voice. According to Emmons (1999), 'Spiritual Intelligence is a framework for identifying and organizing the skills and abilities needed for adaptive use of spirituality'. Emmons labelled five components of Spiritual Intelligence as the capacity to go beyond the physical and material world, the ability to experience heightened statuses of consciousness, the ability to make sacred everyday experiences, the ability to employ spiritual resources to problem-solving ability, and the ability to be righteous. Kate Diane Noble (2001) is of conclusion that "Spiritual Intelligence is an inborn human potential that can be an impetus for mental development and mending. Spiritual Intelligence is certainly not a static item, yet a dynamic and fluid process that can change one's personal and social life". Huma Hilal, et.al (2013) had carried out a study to examine the spiritual intelligence among professional and non-professional students. A sample of 400 students was used; 200 students were those who offered professional courses and 200 were those who offered non-professional courses from Aligarh Muslim University. The findings of this study clearly show that professional and non-professional students differ significantly so far as their spiritual intelligence is concerned. Ruiz (2005)gave amazing results about the spiritual dimension in educational leadership. This study explored the use of spirituality by successful educational leaders, to strengthen their effectiveness as it related to schools and their performance. Patneaude (2006) explored the spiritual wellness of undergraduate college students, the findings showed that spiritual wellness played an important part in the lives of college students and the decisions they made on a daily basis regarding the other dimensions of wellness.

As we all know that today's students are facing more challenges and opportunities in the age of google world. To reduce students' stress and improve their social adjustment is very important issue. Spiritual intelligence as a new notion introduced into the system of intelligence has a significant effect on the quality of life and success of students in this present age. Spiritual intelligence plays a significant role in directing and shaping behavior and personality of an individual. Some persons are highly aware of their own spiritual intelligence and their thoughts about them, but others seem to be as almost totally oblivious or unconscious of these. In an age where there is enormous psychological pressure on the youth to perform well and succeed in life, life satisfaction depends on managing ourselves and handling our relationships more artfully. A person who has developed a spiritual intelligence is better equipped not only to monitor his own and others' feelings and emotions but is also able to discriminate among them. Life satisfaction not only depends on what people have but also on the criteria that what people choose 
themselves and how they choose their own achievements. Spirituality is an important component which gives meaning and direction to the life. It is the intelligence with which we balance meaning and value for life and place our lives in a wider context. It involves development of positive morals, ethics and values, which help to promote interpersonal relationships. Sense of self empathy, kindness, intuition, motivation, awareness, social skills, forgiveness, reconciliation, dedication are some of the major components of spiritual intelligence. All these aspects are also very much needed for life satisfaction of the individuals.

\section{Objectives}

- To study the level of spiritual intelligence of post-graduate students.

- To study the difference in spiritual intelligence of male and female post-graduate students.

- To study the difference in spiritual intelligence of rural and urban post-graduate students.

\section{Hypothesis}

- There is no significant difference in spiritual intelligence of male and female post-graduate students.

- There is no significant difference in spiritual intelligence of rural and urban post-graduate students.

\section{Sample}

The sample for the study was selected from postgraduate departments of the Kashmir university in the Kashmir region of the state of Jammu and Kashmir by using stratified random sampling. The study consists of 302 students with 151 rural and 151 urban students. The sample of 151 rural students were further divided into 76 males and 75 females and the sample of 151 urban students were also further divided into 76 males and 75 females.

\section{A Tool Used}

Spiritual intelligence scale of K.S. Mishra (2014)was used for data collection. This scale consists of 42 items for the assessment of spiritual understanding, beliefs, effort, outlook and reasoning. Guttmann Split-half reliability coefficient for spiritual intelligence scale are 0.864 for UG-PG students sample $(\mathrm{N}=180)$ and 0.852 for 9-11 class standard $(\mathrm{N}=160)$. Item validity has been calculated by finding out the correlation between scores on each item and scores on the spiritual intelligence scale. The value of cronbanch's alpha coefficient is 0.890 and 0.874 respectively. The correlation ranged from 0.184 to 0.610 . The spiritual intelligence scale may be administered individually as well as in the group. There is no fixed time limit for the responses. But usually respondents take 40-50 minutes of completing the whole scale.

\section{Statistical Treatment}

Descriptive survey method was used in this study in order to find out the Mean, Standard Deviation and tvalue of the analyzed data.

\section{Statistical Analysis and Interpretation}

Firstly, by keeping in mind the objectives of the study, the researcher studied the level of spiritual intelligence of post-graduate students. On the basis of levels as given in the manual of the scales as low level, average level 


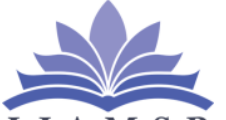

I J A M S R

International Journal of Advanced Multidisciplinary Scientific Research (IJAMSR) ISSN:2581-4281

and high level. After that the investigator used t-test to find significant differences in spiritual intelligence of post-graduate students on the basis of gender and locale. Details pertaining to the analysis are being given separately as follows.

Levels of Spiritual Intelligence of Postgraduate Students

In order to explore the level of spiritual intelligence of post-graduate students of Kashmir, the investigator used spiritual intelligence scale for collecting information from subjects. The scores of the spiritual intelligence scale were calculated and divided into three groups on the basis of values given in the norms of the manual i.e. low spiritual intelligence group (LSIG) those who scores less than 177, average spiritual intelligence group (ASIG) having scores between 178-193 and high spiritual intelligence group (HSIG) having scores higher than 194 . The results have been presented in the table 1

Table 1. Level of Spiritual Intelligence among PostGraduate Students

\begin{tabular}{|c|c|c|}
\hline Levels & N & Percentage \\
\hline HSIG & 77 & $25.50 \%$ \\
\hline ASIG & 152 & $50.33 \%$ \\
\hline LSIG & 73 & $24.17 \%$ \\
\hline
\end{tabular}

The results of the table 1 revealed that $25.50 \%$ postgraduate students have high spiritual intelligence, $50.33 \%$ have average spiritual intelligence and $24.17 \%$ have low spiritual intelligence. It means the majority of post-graduate students falls in the average level of spiritual intelligence. The result of the above table has been presented graphically through the figure 1

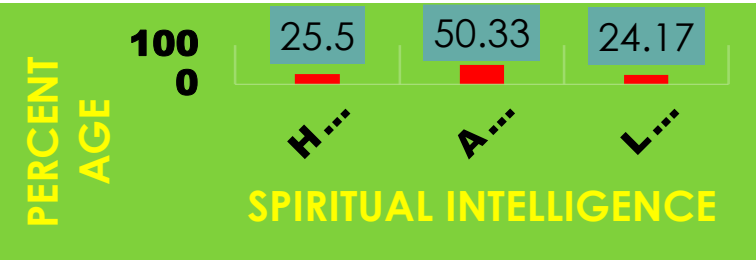

Figure 1. Level of Spiritual Intelligence among Postgraduate Students

Difference in spiritual intelligence of male and female post-graduate students of Kashmir

The second objective of the study was to analyze the difference in spiritual intelligence of male and female post graduate students of Kashmir. To achieve this objective, the spiritual intelligence scores of male and female post graduate students of Kashmir were compared using t-test. Means, Standard deviation and Summary of t-test have been presented in the table 2

Table 2. Difference in Spiritual Intelligence of Male and Female, Postgraduate Students

\begin{tabular}{|c|l|l|l|c|c|}
\hline $\begin{array}{c}\text { Gro } \\
\text { up }\end{array}$ & N & $\begin{array}{c}\text { Me } \\
\text { an }\end{array}$ & SD & $\begin{array}{c}\text { t- } \\
\text { val } \\
\text { ue }\end{array}$ & Result \\
\cline { 1 - 3 } $\begin{array}{c}\text { Mal } \\
\text { e }\end{array}$ & 1 & 185 & $\begin{array}{c}11 . \\
.23\end{array}$ & $\begin{array}{c}1.2 \\
0\end{array}$ & $\begin{array}{c}\text { Insignifi } \\
\text { cant }\end{array}$ \\
\cline { 1 - 3 } $\begin{array}{c}\text { Fem } \\
\text { ale }\end{array}$ & $\begin{array}{l}1 \\
4\end{array}$ & $\begin{array}{c}183 \\
.48\end{array}$ & $\begin{array}{c}13 . \\
25\end{array}$ & & \\
\hline
\end{tabular}

Insignificant at both 0.01 levels $\&$ 0.05 levels

The table 2 showed that the mean difference between male and female post-graduate students in their spiritual intelligence scores. The table reflects that the mean score of male post-graduate students was 185.23 and female post-graduate students were 183.48 and standard deviation of male students was 11.95 and female students was 13.25 respectively, $t$-value found to be 1.20 which was insignificant at both 0.01 levels as well as 0.05 level of significance. This means that there was insignificant or no difference in spiritual intelligence of male and female post-graduate students. Therefore, the first hypothesis of the study, which was stated that 


\section{International Journal of Advanced Multidisciplinary Scientific Research (IJAMSR) ISSN:2581-4281}

"There is no significant difference in spiritual intelligence scores of male and female post-graduate students." stands accepted, because there was an insignificant difference in the spiritual intelligence scores of male and female post-graduate students. Gupta (2012) \& Nazam (2014) in their studies found that male students have higher spiritual intelligence as compared to female students. Their findings are against the findings of the present study which revealed that male students have not higher spiritual intelligence in comparison to female students. This may be due to the fact that both male and female students were preferred for quality education by their parents in nowadays. In our earlier society generally male students participate in seminars, debates and other social activities as compared to female students who are always considered as dependable and weaker section of our society. Female students are always feeling insecure in our societies due to ever-growing inhuman acts, social crimes and crisis. Due to their insecurity the female students do not participate in all the activities of the society as male students does. Modern inventions, laws, norms and discoveries in the field of education and communication have brought both male and female students on the same track with which the earlier differences as well as hindrances have been ended. These knowledge exchange activities and social interactions help both male and female students to develop spiritually and also both male as well as female students often visit religious places and gatherings where people are taught about morality and spirituality by religious and social preachers. Due to these reasons we can say that no differences have remained between scores of spiritual intelligence of male and female post-graduate students.

Difference in spiritual intelligence of rural, urban post-graduate students

The third objective of the study was to analyze the difference in spiritual intelligence of rural and urban post graduate students of Kashmir. To achieve this objective, the spiritual intelligence scores of rural and urban post graduate students of Kashmir were compared using ttest. Means, Standard deviation and Summary of t-test have been presented in the table 3

Table 3. Difference in Spiritual Intelligence of Rural and Urban Post-Graduate Students.

\begin{tabular}{|c|l|l|l|l|l|}
\hline $\begin{array}{c}\text { Gro } \\
\text { up }\end{array}$ & $\mathbf{N}$ & $\begin{array}{c}\text { Me } \\
\text { an }\end{array}$ & SD & $\begin{array}{c}\text { t- } \\
\text { val } \\
\text { ue }\end{array}$ & Result \\
\hline $\begin{array}{c}\text { Rur } \\
\text { al }\end{array}$ & 1 & 184 & 12. & & \\
2 & .42 & 57 & 0.0 & $\begin{array}{c}\text { Insignifi } \\
\text { cant }\end{array}$ \\
\cline { 1 - 2 } Urb & 1 & 184 & 12. & 7 & \\
an & 5 & .31 & 74 & & \\
\hline
\end{tabular}

\section{Insignificant at both 0.01 level and 0.05 level}

The table 3 showed that the mean difference between rural and urban post-graduate students in their spiritual intelligence scores. The table reflects that the mean score of rural post-graduate students was 184.42 and urban post-graduate students were 184.31 and standard deviation of rural students was 12.57 and urban students was 12.74 respectively, $t$-value found to be 0.07 which is insignificant. This means that there was no significant difference in spiritual intelligence of rural and urban post-graduate students. Therefore, a second hypothesis of the study, which was stated that "There exists no significant difference in spiritual intelligence scores of 


\section{International Journal of Advanced Multidisciplinary Scientific Research (IJAMSR) ISSN:2581-4281}

rural and urban post-graduate students.” stands accepted, because there was no significant difference in the spiritual intelligence scores of rural and urban postgraduate students. To the best knowledge of the researcher no study has been conducted so far which can support or stand against the findings of the present study. The findings of the present study revealed that there was no significant difference between scores of spiritual intelligence of rural and urban post-graduate students. This may be due to the fact that the advancements in information technology have made a strong impact on almost all areas or regions of our country as well as the world as a whole. The new messaging apps have options to set up rural and urban groups where one can interact with other members of the society despite where they are. Due to these advancements in the world has been made as a global village. The influence of information technology on religious practices has mainly been to the effect of making information about them more accessible. In the field of education with the help of information technology, we have a virtual class where the instructor could sit in any part of the world and his students scattered in all different parts of the world through video conference with presentation of study materials as well as question and answer sessions. The rural and urban students nowadays are also being provided the same opportunities as well as facilities for inculcating in them the roots of spirituality, moral education, religious education \& social competencies for developing their goals and implementing spiritual intelligence in their learning behavior. Due to these reasons we can say that no difference has remained between scores of spiritual intelligence of rural and urban post-graduate students.
On the basis of the various results obtained, some important conclusions have been derived and these are being presented below.

i. $\quad 24.17 \%$ post-graduate students have a low level of spiritual intelligence; $50.33 \%$ post-graduate students have an average level of spiritual intelligence while as $25.50 \%$ post-graduate students have higher level of spiritual intelligence.

ii. Gender wise two groups of postgraduate students, i.e. male and female students do not differ in their Spiritual Intelligence. Hence it may be concluded that spiritual intelligence is a gender free construct.

iii. Locale wise two groups of postgraduate students, i.e. urban and rural do not differ in their Spiritual Intelligence. Hence it may be concluded that Urban Postgraduate students are not better in spiritual intelligence as compared to their rural post-graduate students.

\section{Acknowledgments}

The author appreciates all those who participated in the study and helped to facilitate the research process.

\section{Conflict of Interests}

The author declared no conflict of interests.

\section{Conclusion}


https://doi.org/10.31426/ijamsr.2018.1.10.1020

\section{International Journal of Advanced Multidisciplinary Scientific Research (IJAMSR) ISSN:2581-4281}

\section{References}

1) Best, John W. (1982). Research in science education. 4th Ed., New Delhi: Prentice Hall of India Private Limited.

2) Emmons, R. A. (1999). The Psychology of Ultimate Concerns. New York: The Guildford Press.

3) Gardner, H. 1999. Intelligence reframed: multiple intelligences for the 21st century. New York: Basic.

4) Hosseini, M., Elias, H., Krauss, S. E., \&Aishah, S. (2010). A Review Study on Spiritual Intelligence, Adolescence and Spiritual Intelligence, Factors that May Contribute to Individual Differences in Spiritual Intelligence, and the Related Theories. International Journal ofPsychological Studies. Vol. 2, No. 2.

5) Mangal, S.K., (1993). Advanced Educational Psychology, Prentice Hall, New Delhi, India.

6) Spearman, C. (1904). "General intelligence," Objectively Determined and Measured. American Journal of Psychology, 15 (2): 201-293.

7) Sisk, D.A., \& E. P. Torrance. (2001). Spiritual Intelligence: Developing Higher Consciousness. Ist Edn. Creative Education Foundation, Buffalo, NY., pp.196.

8) Tankamani, N., \& Haghighat, S. (2014). Relationship between spiritual intelligence, optimism with resilience in students. Epistemologia, 11 (2), $375-381$. Retrieved from www.epistemologiajournal.com

9) Zohar, D., and Marshall, I. (2000). SQ: Connecting with our spiritual intelligence. New York: Bloomsbury Publishing.

10) Zohar, D., and Marshall, I. (2004). Spiritual Capital: Wealth we can live by. San Francisco: BerrettKoehler Publishers Inc. 